\title{
PERLINDUNGAN HUKUM BAGI PERUSAHAAN LEASING TERHADAP DEBITUR WANPRESTASI
}

\author{
Ni Luh Ayu Regita Cahyani, I Nyoman Putu Budiarta, Ni Made Puspasutari Ujianti \\ rcahyani107@gmail.com, budiarthaputu59@gmail.com, puspautariujianti@gmail.com \\ Fakultas Hukum, Universitas Warmadewa, Denpasar-Bali, Indonesia
}

\begin{abstract}
Abstrak
Dalam perusahaan leasing sering terjadi sengketa salah satunya adalah wanprestasi. Kegiatan ini dilakukan oleh pihak debitur yang seharusnya memiliki kewajiban dalam melaksanakan prestasi dalam suatu kontrak terhadap perusahaan leasing. Tujuan penelitian ini yaitu untuk mengungkap bentuk perlindungan hukum bagi perusahaan leasing dan akibat hukum yang timbul apabila debitur melakukan wanpretasi. Penelitian ini menggunakan penelitian hukum normatif, yang dikaji menggunakan studi kepustakaan. Sumber bahan hukum yang digunakan adalah bahan hukum primer dan bahan hukum tersier yang dapat menunjang bahan hukum sekunder. Bahanbahan yang telah didapat kemudian dianalisis menggunakan teknik deskripsi, yang dimana teknik ini memaparkan isu hukum yang kemudian ditafsirkan dengan sistematis dan gramatika. Hasil penelitian mengungkapkan bahwa perjanjian standar yang diberikan oleh pihak leasing didalamnya berisi mengenai hak dan kewajiban yang dibebankan kepada pihak debitur dan apabila kewajiban tidak dapat dipenuhi maka dapat diberikan somasi kepada pihak debitur apabila kewajiban tidak juga dipenuhi maka barang modal yang menjadi objek dapat ditarik, akibatnya pihak debitur dapat kehilangan hak atas barang tersebut dan pihak leasing dapat mengakhiri perjanjian secara sepihak.
\end{abstract}

Kata Kunci: Debitur, Perusahaan Leasing, Wanprestasi

\begin{abstract}
Disputes often occur in leasing companies, one of them is breach of content. This activity is carried out by the debtor who should have an obligation to carry out achievements in a contract against the leasing company. The purpose of this research is to reveal the form of legal protection for leasing companies and the legal consequences that arise when the debtor makes an interpretation. This research uses normative legal research, which is studied using literature research. Sources of legal materials used are primary legal materials and tertiary legal materials which can support secondary legal materials. The materials that have been obtained are then analyzed using descriptive techniques, where this technique describes legal issues which are then interpreted systematically and grammatically. The results of the research reveal that the standard agreement provided by the leasing party contains rights and obligations that are borne by the debtor and if the obligations cannot be fulfilled, then a subpoena can be given to the debtor if the obligations are not fulfilled, the capital goods that become the object can be withdrawn, as a result. the debtor can lose the rights to the item and the leasing party can terminate the agreement unilaterally.
\end{abstract}

Keywords: Debtors, Leasing Companies, Default

\section{PENDAHULUAN}

Dalam upaya meningkatnya perkembangan sektor perekonomian, banyak pelaku usaha baik itu perorangan maupun yang berbadan hukum sekalipun membutuhkan pendanaan dalam menjalankan usahanya. Guna mernbantu pelaku usaha dalam hal pendanaan maka bank, pegadaian dan lembaga keuangan bukan bank diharapkan dapat menampung dan membantu pelaku usaha dalam hal permodalan dalam bisnisnya. Pelaku usaha tidak bisa hanya mengandalkan dana atau modal yang dimiliki sendiri, melainkan juga harus mendapat dana dari mekanisme pinjam meminjam atau perjanjian kredit dari suatu Lembaga keuangan. Kredit diberikan atas dasar kepercayaan dengan pemberian fasilitas terhadap kredit kepada debitur itu sendiri dengan maksud dan tujuan agar fasilitas kredit yang telah diberikan dapat kembali dengan aman dan menguntungkan (Widiyono, 2009).

Janji yang telah disepakati baik itu yang terdapat didalam perjanjian pokok dan perjanjian penajminannya, para pihak yang terlibat dapat membuat perjanjian, apabila debitur itu sendiri tidak 
patuh akan janji-janji yang telah disepakati dalam perjanjian makan perjanjian tersebut dapat ditutup dan hutang debitur dapat ditagih secepatnya (Satriyo, 2005). Lembaga pembiayaan yang perkembangannya cukup pesat saat ini adalah sewa guna usaha atau yang sering disebut leasing. Leasing merupakan suatu kegiatan pembiayaan dalam bentuk penyediaan dan pengadaan barangbarang modal baik itu secara sewa guna usaha dengan opsi atau tanpa opsi, unruk dapat dipergunakan oleh Lessee secara berkala sesuai dengan ketentuan pembayaran secara berkala dalam perjanjian yang telah disepakati.

Leasing merupakan salah satu cara yang dapat dilakukan oleh suaru perusahaan dalam memperoleh aset yang mereka butuhkan atau kepemilikan terhadap suatu barang tanpa melalui proses yang berkepanjangan. Pengadaan barang tersebut semuanya telah diatur oleh perusahaan leasing sesuai dengan apa yang sudah disediakan perusahaan. Leasing juga dapat menghindarkan pelaku usaha terhadap resiko tinggi yang saat ini sudah disadari secara langsung oleh pelaku usaha.

Salah satu contoh pengadaan barang oleh leasing adalah di bidang otomotif dimana supplier melakukan kerjasama dengan perusahaan pembiayaan, agar penjualan kendaraan dapat terjangkau bagi masyarakat dengan sistem kredit, serta dapat memberikan keuntungan bagi masyarakat karena proses dan kendaraan dapat diterima dengan cepat. Hal tersebut bisa terjadi karena perusahaan guna usaha telah melunasi pembayaran kepada supplier secara runai.

Perusahaan yang bergerak dibidang guna usaha ini selalu mencari nasabah dengan ketentuan yang telah disesuaikan dengan syarat-syarat yang sudah ditetapkan oleh perusahaan guna usaha. Penjualan dilakukan dengan sistem kredit dan dan objek akan diberikan kepada lessor untuk dilakukan pembayaran secara kredit, yang didalamnya mencakup pokok pengembalian jumlah dan bunganya. Meningkatnya kebutuhan masyarakat akan barang-barang elektronik dan kendaraan bermotor atau barang-barang yang pada umumnya memiliki harga yang cukup tinggi, maka diharapkan pihak swasta melalui perusahaan leasing sebagai salah satu sarana alternatif dalam pemenuhan kebutuhan tersebut melalui sistem kredit. Pada umumnya ada dua jenis pembiayaan yang disediakan oleh pihak leasing yaitu financial lease dan operating lease (Nahrowi, 2013).

Keuntungan dari adanya perusahaan leasing adalah pembayaran uang muka dan kreditnya lebih murah daripada pinjaman langsung. Hal ini bisa terjadi dikarenakan leasing mengandung penurunan pajak dari barang-barang yang dileasingkan. Atas dasar tersebutlah lessee dapat memiliki barang tanpa modal dan dana yang besar untuk membeli barang tersebut (Wahyuningsih, 2013). Perusahaan leasing menyediakan modal yang cukup besar dalam upaya pemenuhan barang untuk pihak lessor, maka kerap kali terjadi wanprestasi dari pihak lessor itu sendiri. Sering terjadinya pemindahan hal yang dilakukan oleh Lessee karena dilatarbelakangi oleh sebab ekonomi, maka proses pengalihan tersebut berakibat hukum, yang dimana akibat hukum dari objek tersebut menyangkut hak-hak dari pihak ketiga yang menerima pengalihan barang tersebut.

Perihal pengalihan atas barang tersebut didasari oleh tidak sanggup debitur melakukan pembayaran kredit, hal tersebutlah yang menyebabkan terjadinya wanprestasi yang dilakukan oleh pihak lesseee atau debitur. Wanprestasi yang dilakukan oleh debitur tersebut dapat memberikan kerugian kepada kreditur yang dimana kreditur seharusnya berhak atas penerimaan prestasi. Yang di maksud dari wanprestasi adalah tidak dipenuhinya kewajiban atau tanggung jawab yang telah disepakati dalam perikatan, baik itu perikatan yang timbul karena perjanjian atau perikatan yang timbul karena undang-undang. Wanprestasi dapat diartkan juga sebagai ketidakterlaksannya prestasi yang seharusnya dilakukan oleh debitur. Sedangkan prestasi adalah perikatan yang bertujuan untuk memberikan sesuatu, menjalankan sesuatu, menerima sesuatu, berbuat sesuatu atau tidak berbuat sesuatu, sesuai dengan yang dijelaskan didalam pasal 1234 KUHPerdata. Prestasi juga dapat diartikan sebagai isi yang tertuang didalam sebuah perjanjian yang didalamnya berisi hak dan kewajiban yang harus dipenuhi oleh kedua belah pihak yang telah menyepakati perjanjian tersebut.

Wanprestasi seringkali terjadi dalam praktek leasing, contohnya tidak membayar denda, menunda pembayaran sewa hingga jatuh tempo maupun melepaskan tanggungjawab dalam pembayaran sewa (Maramis, 2013). Kelalaian yang dilakukan oleh lesseee dapat merugikan lessor terutama apabila kelailaian berpengaruh secara langsung terhadap obyek leasing. Maka diperlukan suatu upaya perlindungan hukum demi kepentingan lessor agar terhindar dari resiko kerugian atau kehilangan obyek leasing (Hartono, 2007). Menurut Aprilianti (2011) apabila wanpretasi yang dilakukan oleh lesseee telah terjadi, maka tindakan yang harus dilakukan oleh lessor adalah memberikan somasi untuk memenuhi prestasi yang tertunda sesuai dengan tanggal yang telah 
ditetapkan. Namun jika pihak lessee tidak melaksanakan kewajibannya, maka tindakan selanjutnya yaitu menarik kembali objek sewa guna usaha dengan membebankan biaya penarikan kepada lessee serta ditandai dengan berakhirnya perjanjian antara kedua pihak yang mengharuskan lessee memenuhi semua kewajiban atas semua biaya yang dikenakan kepadanya.

Maka berdasarkan uraian diatas, tujuan dari penelitian ini yaitu mengungkapkan bentuk perlindungan hukum bagi perusahaan leasing dan akibat hukum yang timbul apabila debitur melakukan wanpretasi.

\section{METODE PENELITIAN}

Penelitian ini termasuk kedalam penelitian hukum normatif guna mengembangkan pengetahuan dalam berbagai pandangan yang dijelaskan para ilmuan hukum (Atmadja \& Budiartha, 2018) dengan pengkajian menggunakan studi kepustakaan yang berupa bahan-bahan hukum dan berdasar pada norma-norma yang ada. Pendekatan masalah yang digunakan dalam penelitian ini adalah pendekatan perundang-undangan dan pendekatan konseptual yang menekankan pada pandangan dan doktrindoktrin yang berkembang dalam ilmu hukum. Teknik pengumpulan bahan hukum yang digunakan adalah bahan hukum primer yang didapat dengan menganalisis peraturan perundang-undangan, risalah resmi, dan beberapa keputusan-keputusan yang menyangkut dengan judul penelitian ini. bahan hukum sekunder didapat dari menganalisis buku, jurnal dan hasil penelitian terdahulu yang memiliki keterkaitan dengan judul penulisan ini. Dan bahan hukum tersier yang dapat rnenunjang bahan hukum primer dan sekunder seperti kamus-kamus hukum dan tulisan yang dapat diakses melalui internet. Bahan-bahan yang telah didapat kemudian dianalisis menggunakan teknik deskripsi, yang dimana teknik ini memaparkan isu hukum dengan menguraikan secara rinci bahan-bahan yang telah disediakan, yang kemudian ditafsirkan dengan sistematis dan gramatika yang merupakan penafsiran yang menitikberatkan pada kaitan pengaruran hukum yang satu dengan yang lainnya serta mencari artikel yang memiliki substansi yang sama dengan tema penulisan dan menggunakan bahasa hukum hukum.

\section{HASIL DAN PEMBAHASAN}

\section{Bentuk Perlindungan Hukum bagi Perusahaan Leasing}

Perjanjian dan kontrak memiliki makna yang sama, yaitu peristiwa dimana dua orang atau lebih telah sepakat akan suatu perbuatan tertentu, dan dituangkan secara tertulis. Pihak-pihak yang terlibat dala suatu perjanjian atau kontrak memiliki hak dan kewajiban saru sama lain dan harus dipenuhi dan apabila terjadi pengingkaran atau wanprestasi terhadap kontrak tersebut maka dapat dikenakan sanksi sesuai dengan yang telah disepakati bersama (H.S., 2006).

Dalam pembuatan suatu perjanjian ada beberapa syarat yang harus dipenuhi di dalamnya, yaitu sepakat bahwa kedua belah pihak mengingat dirinya dengan perjanjian tersebut, kecakapan atas dirinya untuk membuat suatu perjanjian, adanya hal tertentu yang ingin disepakati, adanya sebab yang halal yang mendasari terbentuknya suatu perjanjian, sesuai dengan yang dijelaskan dalam pasal 1320 KUHPerdata. Kredit adalah penyediaan uang yang berupa tagihan dan akan dibayarkan sesuai dengan perjanjian atau kesepakatan pinjam meminjam baik itu dengan bank atau perusahaan yang bergerak dibidang penyediaan dana (leasing) dan mewajibkan pihak yang meminjam untuk melunasi tagihannya dan beserta bunganya.

Perjanjian kredit adalah kesepakatan yang telah disepakati oleh pihak kreditur dan debitur, yang dimana didalamnya bersi tentang hak dan kewajiban dari masing-masing pihak. Perjanjian kredit berfungsi untuk membatasi hak dan kewajiban dari kedua belah pihak, perjanjian kredit juga berfungsi sebagai alat yang digunakan untuk memonitoring kedua belah pihak. Untuk menghindari wanprestasi atau tidak patuhnya debitur akan kewajibannya, maka pihak kreditur harus memperhatikan keadaan debitur baik itu aset yang dimiliki dan pekerjaan dari debitur itu sendiri. Karena pada dasarnya kredirur memberikan kredit kepada debirur berdasarkan pada kepercayaan dan kehati-hatian.

Prinsip kepercayaan adalah kepercayaan dari pihak bank selaku kreditur terhadap debirur bahwa kredit yang diberikan dapat bermanfaat bagi debitur sesuai dengan yang dibutuhkan dan pihak bank selaku kreditur percaya bahwa pihak debitur dapat melakukan pembayaran rutin sampe pelunasan kredit beserta bunganya. Prinsip kehati-hatian adalah prinsip yang dijalankan dengan penuh perhirungan matang dari pihak bank selaku kredirur dalam memberikan kredit pada pihak debirur, 
kehati-hatian tersebut dapat dilakukan dengan cara melakukan survey terhadap aset yang dimiliki oleh debitur serta pekerjaan dari debitur itu sendiri, karena kedua hal tersebutlah yang dapat menunjang debitur dalam melunasi kreditnya. Kredit merupakan transaksi yang menggunakan jumlah modal yang besar dan memiliki kemungkinan besar terjadinya kelalaian baik disengaja atau tidak disengaja oleh pihak debitur. Untuk melindungi keamanan dan kenyamanan dari kreditur itu sendiri, maka kreditur berhak meminta jaminan atas suatu pinjaman yang diajukan oleh debitur dan biasanya nilai kredit dan jaminannya memiliki jumlah atau rentang harga yang sama.

Mengingat resiko yang mungkin dihadapi oleh kreditur, maka dalam pelaksanaannya berbagai jaminan yang diharapkan dapat meminimalisir kerugian yang akan ditirnbulkan dari wanprestasi yang dilakukan oleh debitur. Jarninan hutang yang dapat diserahkan ke leasing dapat dikelompokkan menjadi jaminan utama, jaminan pokok dan jaminan tambahan. Bagi pihak kreditur kepastian hukum merupakan hal yang sangat penting guna memberikan perlindungan hukum terhadap perjanjian duna sewa atau teasing. Pasal 9 huruf (f) dan (h) menyatakan bahwa penetapan kerugian yang harus ditanggung oleh pihak lessee dalam konteks ini yaitu barang yang disewa guna usaha menjadi hilang rusak dan tidak bersfungsi karena suatu sebab tertentu.

Ketentuan mengenai sanksi telah diarur dalam pasal 1237 ayat 2, 1243-1252, pasal 1266 KUH Perdata dan pasal 181 HIR. Selain para pihak yang terlibat dalam perjanjian, pihak leasing juga bisa menetapkan sanksi-sanksi yang akan mereka jatuhkan data perjanjian yang telah disepakati bersama dengan syarat dan batasan-batasan yang tertuang dalam KUHPerdata.

\section{Akibat Hukum yang Timbul Apabila Debitur Melakukan Wanpretasi}

Dalam suatu perjanjian, apabila terjadi wanprestasi di dalamnya maka dapat mengakibatkan salah satu pihak dalam perjanjian tersebut dirugikan. Karena terjadinya suatu kerugian dari salah saru pihak, pihak yang melakukan wanprestasi harus menanggung akibat dari tindakannya berupa runtutan dari pihak lawan yang dapat berupa, pembatalan kontrak dan pemenuhan kontrak.

Jika pembatalan dan pemenuhan kontrak dijabarkan lebih detail maka dapat dibagi menjadi empat, yaitu pembatalan kontrak saja, pembatalan kontrak dengan disertai ganti rugi, pemenuhan kontrak saja dan pemenuhan kontrak disertai dengan tuntutan ganti rugi. Tuntutan yang dapat diajukan oleh lessor kepada lessee adalah lessee diharuskan membayarkan ganti rugi yang dialami oleh lessor, wanprestasi dari satu pihak memberikan pihak lainnya wewenang untuk membatalkan suatu kontrak atau memutuskannya lewat putusan hakim, dapat dilakukan pembatalan perjanjian berupa pemenuhan alas pembayaran ganti rugi yang dialami oleh lessor, membayar biaya perkara yang diperkarakan di pengadilan.

Wanprestasi itu sendiri memiliki akibat-akibat yang penting, maka harus dipastikan terlebih dahulu apakah lessee memang benar melakukan wanprestasi atau hanya melakukan kelalaian dan apabila disangkal oleh lessee maka harus dibuktikan di depan hakim. Lessee juga dapat melakukan pembelaan apabila merasa tidak melakukan wanprestasi dengan melampirkan atau menyertakan bukti bukti di hadapan hakim. Bukti-bukti yang dapat membebaskan lessee dari dugaan wanprestasi adalah tidak terjadinya pemenuhan kontrak karena keadaan yang mernaksa, tidak memenuhi kontrak karena pihak lain juga melakukan wanprestasi dan tidak dipenuhinya kontrak karena pihak lainnya telah melepaskan haknya atas prestasi (Muhammad, 1993).

Seperti layaknya perjanjian pada umumnya, apabila lessee melalukan wanprestasi maka pihak lessor selaku kreditur berhak atas pemenuan prestasi dan ganti rugi sesuai dengan yang dijelaskan dalam PasaJ 1267 KUHPerdata. Menuntut dan meminta ganti rugi hanya dapat dilakukan apabila terjadi keterlambatan pembayaran kredit dan pembatalan perjanjian sepihak. Upaya yang dilakukan untuk menghindari kesulitan yang dialamu oleh pihak leasing dalam pengambilan objek jaminan adalah dicantumkannya klausa yang mana dapat mempermudah lessor dalam pelaksanaan akan haknya terhadap objek leasing tersebut.

Kewajiban-kewajiban yang diberikan kepada pihak lessor apabila melakukan wanprestasi adalah mengganti kerugian, benda yang menjadi objek jaminan dalam perjanjian saat tanggung jawab tidak dipenuhi maka objek tersebut menjadi tanggung jawab pihak lessee dan perikatan yang timbal batik memberikan pihak lessor kewenangan dalam pemutusan atas perjanjian. Lessee melakukan wanprestasi seperti yang tersebut diatas, maka lessor dapat mengirim somasi kepada lessee, somasi tersebut berisi atas tuntutan pemenuhan pembayaran dari pihak lessor terhadap pihak lessor. Jika setelah diberikan somasi tersebut pihak lessee tidak kunjung melakukan kewajibannya, maka tindakan 
selanjutnya yang bisa dilakukan oleh lessor adalah menarik jaminan objek dan membebankan biaya penarikan kepada lesse dengan cara mempercepat pengakhiran perjanjian.

Akibat yang dapat ditimbulkan dari wanpretasi yang dilakukan oleh pihak lessor adalah kehilangan hak atas objek yang dijadikan jaminan, perjanjian dapat diselesaikan secara sepihak oleh pihak lessor dan pembenanan biaya yang ditimbulkan akibat wanprestasi yang dilakukan oleh pihak lessee. Bila wanprestasi ini menimbulkan perselisihan antara pihak lessee dengan lessor maka dapat ditempuh jalur hukum sebagai upaya penyelesaian sengketa ini, tetapi mengingat adanya jaminan objek di dalam perjanjian ini, maka jalur hukum jarang ditempuh dalam penyelesaiannya.

\section{SIMPULAN DAN SARAN \\ 1. Simpulan}

Perlindungan hukum yang dapat digunakan oleh lessor diantaranya dengan memakai alas hukum seperti yang termuat dalam Keputusan Menteri Keuangan Republik Indonesia No.1169/KMKOl/1991 tentang kegiatan Guna Sewa Usaha (leasing) khususnya pada Pasal 6 ayat (I). Sela in itu pada Pasal 7 ayat (3) lessee bertanggung jawab untuk memelihara agar plakat atau etikat yang mencantumkan nama dan alamat lessor tetap melekat pada barang modal yang disewagunakan. Adapun Akibat Hukum Dalam hal lessee melakukan wanprestasi.dalarn suatu perjanjian, bila mana terjadi wanprestasi mengakibatkan pihak lain dirugikan. Pihak wanprestasi harus menanggung akibat dari tuntutan pihak lawan yang berupa tuntutan

1. Lesseee diharuskan membayar ganti kerugian yang telah diderita oleh Lessor (Pas al 1243 KUHPerdata).

2. Dalam perjanjian timbal balik (bilateral) wanprestasi dari suatu pihak memberikan hak kepada pihak lainnya untuk membatalkan atau memutuskan perjanjian lewat hakim (Pasal 1266 KUHPerdata).

3. Resiko beralih kepada lessee sejak saat terjadinya wanprestasi (Pasal 1237 ayat 2 KUHPerdata) ketenruan ini hanya berlaku bagi perikatan untuk memberikan sesuatu.

4. Memenuhi perjanjian jika masih dapat dilakukan atau pembatalan perjanjian disertai dengan pembayaran ganti kerugian (pasal 1267 KUHPerdata), ini berlaku untuk semua perikatan.

5. Membayar biaya perkara apabila perkara diperkarakan di muka hakim (Pasal 181 (1) HIR). Lessee yang terbukti melakukan wanprestasi tentu dilakahkan dalam perkara, ketentuan ini berlaku untuk semua perikatan.

\section{Saran}

Perlu diadakannya suatu peraturan yang lebih lengkap dan efektif menangani perjanjian tentang leasing dengan membuat undang-undang tentang sewa guna usaha (leasing). Hal ini mengingat bahwa peraturan tentang leasing yang selama ini boleh dikatakan sangat sederhana, dan pelaksanaannya selama ini didasarkan pada kebijakan yang tidak bertentangan dengan Surat Keputusan Bersama Tiga Menteri.

\section{DAFTAR PUSTAKA}

Aprilianti. (2011). Perjanjian Sewa Guna Usaha Antara Lesseee dan Lessor. Fiat Justisia Jurnal Ilmu Hukum, 5(3), 315-323.

Atmadja, I. D. G., \& Budiartha, I. N. P. (2018). Teori-Teori Hukum. Setara Press. Malang.

Hartono, D. S. (2007). Perlindungan Hukum bagi Lessor pada Perjanjian Leasing (Studi Kasus pada PT.ACC Cabang Semarang). Jurnal Litbang, 3(2), 22-31.

H.S., S. (2006). Perancangan Kontrak dan Memorandum of Understanding (MoU). Sinar Grafika. Jakarta.

Muhammad, A. K. (1993). Hukum Perdata Indonesia. PT Citra Aditya Bakti. Bandung.

Maramis, D. (2013). Analisis Yuridis Perlindungan Hukum bagi Lessor dalam Perjanjian Leasing. Jurnal Hukum Unsrat, 1(6), 37-45.

Nahrowi. (2013). Permasalahan Hukum Pembiayaan Leasing di Indonesia. Jurnal CITA HUKUM, $1(1), 25-38$.

Satriyo, J. (2005). Hukum Jaminan Hak Jaminan Kebendaan Fidusia. PT Citra Aditya Bakti. Bandung. 
Wahyuningsih, N. (2013). Sewa Cuna Usaha (leasing) dalam Perpektif Syariah. Jumal Al-Amwan, $5(1), 1-12$.

Widiyono, T. (2009). Agunan Kredit dalam Financial Engineering. Ghalia Indonesia. Bogor 